\title{
ДУХОВНО-НРАВСТВЕННЫЕ ЦЕННОСТИ ХРИСТИАНСТВА КАК ОСНОВА МЕЖХРИСТИАНСКИХ ОТНОШЕНИЙ
}

\author{
Е. А. ЛАГУНОВСКАЯ
}

\author{
Брестский государственный университет имени А. С. Пушкина, г. Брест, Беларусь
}

На современном этапе отличительной особенностью социокультурного пространства Республики Беларусь является поликонфессиональность, большинство населения считают себя верующими. Официально зарегистрированы 25 конфессий. Сложившаяся на сегодняшний день конфессиональная структура имеет ярко выраженный христианский характер. Христианские конфессии объединяют более $97 \%$ зарегистрированных религиозных общин. Самой многочисленной христианской конфессией является Белорусская православная церковь (БПЦ). Численность ее общин составляет более $50 \%$ от всех зарегистрированных общин христианских конфессий [8]. Христианство играет определяющую роль в социокультурном пространстве Беларуси и, прежде всего две его основные конфессии - православие и католицизм, история взаимоотношений которых сложна и противоречива.

Ценности христианства как система моральных ориентиров-регулятивов признаются всеми христианскими конфессиями и являются их духовно-нравственной основой. В контексте развития культуры межличностных отношений понятие «христианские ценности» употребляется для обозначения некоторых высших принципов жизни, поведения, норм и идеалов, к которым стремится общество. В социальном пространстве христианские ценности в концентрированной форме выражают то общее, существенное, что объединяет христианские конфессии - нацеленность на духовно-нравственное воспитание личности. Рассмотрение гуманистического потенциала духовно-нравственных ценностей христианства как основы межхристианских отношений в сложных и противоречивых условиях современного развития является актуальной задачей. В силу ряда факторов, объединяющих приверженцев христианства (православия, католицизма, протестантизма) как представителей различных социальных групп (прежде всего их совместная деятельность в социально значимых ситуациях и функционирование в масштабах государства), акцент в осмыслении этой задачи ставится на моральном фундаменте всех христианских конфессий, на том, что объединяет их, а не на различиях в их конфессиональных формах. Первичным источником репрезентации духовно-нравственных ценностей христианства, объединяющим все христианские конфессии, является Священное Писание. Также общей особенностью вероучения всех христианских конфессий (православия, католицизма, протестантизма) и тем, что отличает их от других религий, является вера в Троицу и богочеловечество Иисуса Христа, хотя и с некоторыми особенностями [2, с. 7]. Принимая во внимание черты характера и менталитета белорусского народа, феномены поликультурности и поликонфессиональности, представляется целесообразным в современной белорусской науке наибольший акцент в исследовании социокультурного феномена ценностей христианства сделать на наследие представителей старобелорусской культуры, классиков национальной литературы, а также труды белорусских авторов. Также необходимо принять во внимание тот факт, что духовно-нравственные ценности христианства являются важной составной частью национальной культуры.

На мировоззренческом фундаменте христианских ценностей были сформированы принципы единства, коллективизма, взаимопомощи в период становления белорусской государственности. Данные ценности, определившие личностное отношение к социальной действительности, выразились в ориентациях единения и консолидации перед угрозой завоевания, героизме, патриотизме и др. В период генезиса белорусской государственности понимание заповедей Ветхого Завета, Нагорной проповеди Иисуса Христа, нравственных 
норм повседневной жизни христианства приобрело этническую форму [1]. Эпоха расцвета старобелорусской культуры характеризуется актуализацией моральных норм христианства, устремленностью сознания народа к высшим духовно-нравственным ценностям универсального порядка. Ценности христианства регулировали все сферы общественной и духовной жизни белорусского этноса в процессе формирования старобелорусской культуры, что явилось причиной не только культурных, экономических, дипломатических, но и военных, политических успехов. В старобелорусском обществе система нравственных ценностей христианства выступала как стабилизирующее и консолидирующее основание, на котором строилась духовная жизнь народа. В XXI в. ценности христианства в качестве структурных компонентов нравственной культуры белорусского общества одновременно выступают как его духовно-нравственное наследие (моральный фонд).

Центральной идеей христианства является идея «завета», связывающая воедино «Ветхий завет» и «Новый завет» и обозначающая взаимное обещание верности союза, который Бог заключает со своими избранниками. Новый завет (Союз) Бога с людьми реализуется через великую миссию и крестную смерть (с последующим Воскресением Иисуса Христа) как основа христианского мировоззрения. Богочеловеческая сущность Иисуса проявляется как воплощенное Божественное Слово (Логос). Этот логос представляет собой начало всех начал (вначале было Слово) и времен. Такая трактовка открывает пространство для диалога Бога с человеком, человека с Богом и человека с человеком во имя духовного самовоспитания человека. Троичность диалога христианства - основа современной культуры, определяющая основные направления и пути развития современного диалога, нацеленного на возвышение духовного начала в человеке. Традиционно духовное начало личности чаще всего связывают с общественным и творчески-созидательным характером его жизнедеятельности, с включенностью человека в мир культуры.

Ценности Ветхого завета детерминируют отношения человека с внешним миром и как моральные ориентиры-регулятивы утверждают определенные конструктивные социальные формы поведения, общения, деятельности, отвергая эгоистические и авторитарные нормы и оценки. Ветхозаветный принцип возмездия: «перелом за перелом, око за око, зуб за зуб: как он сделал повреждение на теле человека, так и ему должно сделать» (Левит: 24, 20) нацелен на установление справедливости и утверждение ценности человеческой жизни в условиях Древнего мира. В напряженных условиях коренных социальных перемен Новый завет постулирует терпение и смирение, в отличие от Ветхого завета, выступающего за активность человеческих действий. Подтверждая ветхозаветные ценности, Новый завет дополняет его принципиально новыми нравственными положениями, отличающими христианскую нравственность от традиционных общечеловеческих норм. Ценности Нового завета, конституирующие отношение человека к социальной действительности и к самому себе, основаны на принципе жертвенной любви и доброжелательного отношения ко всем людям: «Вы слышали, что сказано: люби ближнего твоего и ненавидь врага твоего (Левит. 19,17-18). А я говорю: любите врагов ваших (Мф. 5, 21)». Для понимания любви к врагам использовано греческое слово агапе, раскрывающее отношение, превосходящее психологическую привязанность: оно находится в иной, духовной плоскости. Христианское понятие об «агапе» (любовь нисходящая, жертвенная) как духовном единении, направленном на всех людей, на любого ближнего, совершило нравственный переворот в сознании человечества.

Ценность жертвенной любви понимается в Новом завете как основа всех остальных ценностей, квинтэссенция духовности и нравственного совершенства человека. Мучительная смерть Богочеловека во имя спасения человечества является высшим проявлением Божественной любви к людям. Именно Евангельская формула «Бог есть любовь» раскрывает уникальность места христианства в истории религий [3, с. 97].

Духовно-нравственные основы христианства как вероучения и практики, с одной стороны, направляют ум человека к возвышенному (идея Бога); с другой стороны - обращаются к повседневности, что выражается в формах нравственного поведения. Таким образом, происходит постоянная корреляция: трансцендентное - имманентное. Если духовность 
характеризует высшие, «вертикальные» устремления личности, то нравственность - сфера ее «горизонтальных» устремлений, отношений с людьми и обществом.

Как система моральных ориентиров-регулятивов, ценности христианства конституируют отношение личности к внешнему миру, социальной действительности и своему внутреннему миру, что позволяет им выступить основой межхристианских отношений в современных условиях. Нацеленные на согласование повседневных личных и общественных интересов, ценности христианства создают условия для снижения негативных поведенческих интенций человека, несмотря на то, что не фиксируются в законах, т.е. в отличие от политики и права не институционируются. По мнению С. Л. Франка, грех (игнорирование стремления духовного начала личности к развитию в соответствии с моральными принципами) в социальном пространстве соответствует понятию «моральное зло», не предполагающему религиозных убеждений. Система христианских ценностей предоставляет возможность определения морального зла, действие которого в порядке онтогенетическом (в индивидуальном духовном развитии) и филогенетическом (в историческом развитии человечества) производит определенные психологические, духовные и даже физические изменения в природе человека и социума [9, с. 290]. Моральное зло вносит дисгармонию во внутренний мир личности, оказывает дисбалансирующее влияние на происходящие в нем мыслительные, волевые и чувственные процессы. Отсутствие ориентации на духовные ценности обуславливает нравственную деграцию и усиление деструктивных процессов в системе отношений человека с внешним - природным и социальным миром, другими людьми, самим собой.

Модус нравственного отношения человека к внешнему - природному и социальному миру христианство как вероучение и практика определяет через библейские заповеди, духовно-нравственный идеал, принципы поведения, общения и деятельности, нормы и оценки. В отличие от других этических систем, заповеди христианства детерминируют любое нарушение достоинства, свободы и интересов ближнего. Исполнение заповедей, постулирующих ограничение собственных эгоистических желаний ради интересов ближнего, способствуют раскрытию способности любить: «Заповеди: не прелюбодействуй, не убивай, не кради, не лжесвидетельствуй, не пожелай чужого, и все другие заключаются в сем слове: люби ближнего твоего, как самого себя» (Рим. 13, 9). В современных условиях следование евангельским заповедям предоставляет человеку возможность сделать нравственный выбор в процессе принятия решений.

Христианский идеал, воплощенный в личности Иисуса как примере нравственного совершенства, направляет его последователей на развитие духовных аспектов жизнедеятельности: «Будьте совершенны, как совершенен Отец ваш небесный» (Мф. 5, 43). Этот пример эксплицирует смыслообразующую заповедь христианства: «Возлюби Господа Бога твоего... возлюби ближнего твоего, как самого себя; на сих двух заповедях утверждается весь закон и пророки» (Мф. 33, 37-40). Важную роль в преобразовании «абстрактнотеоретической модели» нравственного поведения в «жизненно-практическое образование» играет ее репрезентация в жизни и смерти Иисуса. Творческое развитие и квинтэссенция евангельских принципов в Его личности ориентирует человека (общность) на кардинальные перемены в нравственно-созидательной деятельности. При этом главный акцент делается на развитии способности личности различать добро и зло как осознанный процесс ее свободного выбора [7, с. 227-233]. Таким образом, духовно-нравственный идеал направляет христиан на изменение и самоизменение мировоззренческих основ сознания, отношения и деятельности. Управление данным процессом осуществляется не столько «извне», но, прежде всего, «изнутри», т. е. без опоры на внешние санкции, страх наказания или общественного мнения, т. к. выражает отношение личности к себе и своему внутреннему миру [4, с. 130, 172].

Достижение христианского идеала предполагает реализацию нравственных принципов поведения, общения и деятельности. Данные регулятивы, конституируемые заповедями, способствуют развитию духовного начала человека, нравственных аспектов его жизнедеятельности, характера взаимоотношений между людьми. Их основу составляет 
принцип любви к ближнему, воплощающий суть христианского гуманизма, на протяжении многих веков представлявшего духовный стержень развития европейской цивилизации [5, с. 27]. «Утверждение идеи абсолютного и его идеально образцового присутствия на вершине расплывающейся в бесконечной высоте ценностной иерархической лестнице духовности, отмечает А.С. Майхрович, - предлагало совершенно новый принцип и масштаб понимания и самого духа, а также мира и человека в их идеально сущностном измерении и будущем существовании» [6, с. 18]. Данный смыслообразующий принцип христианства позволяет связать определенную совокупность фактов, знаний, идей и выступает ориентиром для интерпретации повседневных значений индивидуальной и социальной практики, осуществления межличностной коммуникации на нравственной основе.

Духовные ценности христианства, выражая смысл существования человека и его жизнедеятельности, определяют его отношение к себе и своему внутреннему миру. К таким ценностям относятся любовь, достоинство, совесть, свобода, характеризующие степень восхождения человека к христианскому идеалу на основе нравственного самосознания, самооценки, самоконтроля, саморегуляции, самовоспитания, самодисциплины и др., являющихся структурными компонентами процесса внутриличностной рефлексии. Реализация данных ценностей как важнейших проявлений существования человека, является показателем степени его духовности, демократизации и гуманизации общества, взаимной ответственности людей.

Модус нравственного отношения человека к самому себе и своему внутреннему миру в вероучении и практике христианства обусловлен ценностью уникальной человеческой личности - бессмертного, духовного существа, созданного Богом по своему образу и подобию («Возлюби ближнего твоего, как самого себя» Мф. 22,39). В соответствии с христианским пониманием гуманизма, личность любого человека уникальна и бесценна независимо от его сегодняшнего состояния и поведения, т.к. она наделена индивидуальными чертами и свойствами. Поэтому в философии христианства личность ценна сама по себе, а принцип гуманизма распространяется на любого человека, независимо от его социальнополитической, гражданской, любой другой позиции, от реального вклада в жизнь общества. В соответствии с принципом антропоцентризма в гуманистической философии Возрождения личность ценится по мере ее приближения к духовно-нравственному идеалу эпохи. Особенностью принципа антропоцентризма в философии христианства является введение ценности человеческого достоинства, раскрывающее гуманистическое понимание личности, ее духовной свободы и нравственной активности. В современных условиях признание ценности любого человека является критерием духовно-нравственного развития общества.

Ценность любви понимается как основа межхристианских отношений, призванная исполнять роль оператора, выстраивающего перспективы для дискурсивных практик. Репрезентация ценности любви в условиях конкретной социальной действительности играет важную роль в преобразовании теоретической модели нравственного поведения христианина в жизненно-практическую установку, т.к. абстрактный внешний мир значительно легче любить по сравнению с любым человеком, оказавшимся рядом в данный момент времени, к которому необходимо проявить любовь. В жизнедеятельности современного белорусского общества любовь к согражданам и государству является духовной основой построения сильной и процветающей Беларуси.

\section{Литература}

1. Бабосов, Е. М. Идеология белорусского государства: теоретические и практические аспекты / Е. М. Бабосов. - Минск : Амалфея, 2008. - 488 с.

2. Короткая, Т. П. Христианство в Беларуси: история и современность / Т. П. Короткая, А. И. Осипов, В. А. Теплова. - Минск : Молодеж. науч. об-во, 2000. - 71 с.

3. Кураев, А. Христианская философия и пантеизм / А. Кураев. - М. : Изд-во СвятоТроицкой Сергиевой Лавры, 1997. - 228 с. 
4. Лагуноўская, А. А. Хрысціянскія каштоўнасці ў маральным патэнцыяле беларускага народа / А. А. Лагуноўская. - Брэст: БрДУ імя А. С. Пушкіна, 2016. - 200 с.

5. Лаптенок, А. С. Нравственная культура общества: преемственность и новации / А. С. Лаптенок. - Минск: НИО, 1999. - 201 с.

6. Майхрович, А. С. Поиск истинного бытия и человека: Из истории философии и культуры Беларуси / А. С. Майхрович. - Минск: Навука і тэхніка, 1992. - 247 с.

7. Павловская, О. А. Христианская мораль как фактор духовного развития личности / О. А. Павловская // Человек в условиях социальных трансформаций / Т. И. Адуло, О. А. Павловская. - Минск : Белорус. наука, 2006. - С. 220-234.

8. Уполномоченный по делам религий и национальностей. Информация о конфессиональной ситуации в Республике Беларусь [Электронный ресурс]. - Режим доступа : http: //belarus21.by/Articles/1439296790. - Дата доступа : 20.10.2020.

9. Франк, С. Л. Реальность и человек / С. Л. Франк. - СПб. : РХГИ, 1997. - 448 с.

В статье анализируется система духовно-нравственных христианских ценностей как основа межхристианских отношений в контексте современного социального пространства как на уровне взаимоотношений личности с определенной социальной реальностью, так и человека с человеком. В статье представлены ценности христианства, раскрывающие взаимосвязь человека с социальным пространством (библейские заповеди, христианские духовно-нравственные идеалы, принципы поведения, общения и деятельности, нормы и оценки), выражающие личное отношение человека к человеку (любовь как главное нравственное чувство и состояние, духовно-нравственные цели, мотивы, установки и ценностные ориентации). Акцентируется внимание на понимание ценности любви как основы системы христианских ценностей, призванной играть роль оператора, выстраивающего перспективы социальной коммуникации в межхристианских отношениях.

The article analyzes the system of spiritual and moral Christian values as the basis of interChristian relations in the context of modern social space, both at the level of the relationship between a person and a certain social reality, and a person with a person. The article presents the values of Christianity that reveal the relationship between a person and social space (biblical commandments, Christian spiritual and moral ideals, principles of behavior, communication and activity, norms and assessments); expressing the personal attitude of a person to a person (love as the main moral feeling and state, spiritual and moral goals, motives, attitudes and value orientations). Attention is focused on understanding the value of love as the basis of a system of Christian values, designed to play the role of an operator to build social communication perspective in inter-Christian relations. 